\title{
EDITORIAL
}

\author{
AndrZej KostrzewsKi, TAdeusz StryjaKieWicz
}

Kostrzewski A., Stryjakiewicz T., 2014. Editorial. Quaestiones Geographicae 33(2), Bogucki Wydawnictwo Naukowe, Poznań, pp. 5-6. DOI 10.2478/quageo-2014-0010, ISSN 0137-477X.

Tadeusz Stryjakiewicz, Institute of Socio-Economic Geography and Spatial Management, Adam Mickiewicz University, Dzięgielowa 27, 61-131 Poznań, Poland; e-mail: tadek@amu.edu.pl

The year 2014 is special for Quaestiones Geographicae because it marks the 40th anniversary of the journal. Established at Adam Mickiewicz University in Poznań in 1974 as an annual of the then Institute of Geography, today it is published by the Faculty of Geographical and Geological Sciences, the largest geographical unit in Poland in organisational terms. The journal comes out in four volumes per year, two of them in the field of Physical Geography and Geoinformation (the 'blue' version) and two in Human Geography and Spatial Management (the 'green' version).

There is a close link between the 'life cycle' of Quaestiones Geographicae and major events organised by the International Geographical Union. Its first volume of 40 years ago appeared with a view to presenting the scholarly achievements of geographers - mostly from East-Central Europe, then under communist rule - at the IGU Regional Conference in New Zealand and later at the International Geographical Congress in Moscow. In turn, its first Human Geography and Spatial Management volume was published in 2006 on the occasion of the IGU Regional Conference in Brisbane.
The present volume has been prepared on the occasion of the 2014 IGU Regional Conference, this year held in Cracow, Poland (the previous event of similar rank, viz. the IGU Congress, took place in Poland in 1934, or 80 years ago). Quaestiones Geographicae wishes to contribute to this event, so important for the geographical circles, by presenting recent achievements of both, Polish and foreign researchers to the international audience.

The volume opens with articles of a theoretical-methodological nature devoted to urban issues. In the first, Russell C. Weaver presents the evolution of urban geography as a scientific discipline and its research field. In the second article, which is an outcome of an international research project, Tadeusz Stryjakiewicz, Michał Męczyński and Krzysztof Stachowiak discuss the role of creative industries in the process of the post-socialist urban transformation. In turn, Piotr Werner, Piotr Korcelli and Elżbieta Kozubek examine to what extent population potential has been a modulator of land use changes in the metropolitan areas of Poland.

The next two articles focus on the development of Polish regions. Thus, Teresa Czyż seeks 
to identify contemporary determinants of the development of Polish socio-economic regions, while Paweł Churski examines the spatial distribution of areas of economic growth and stagnation in Poland.

The group of articles that follow embraces empirical studies at an international scale, including comparative analyses. Renata Anisiewicz and Tadeusz Palmowski deal with small border traffic and cross-border tourism between Poland and the Kaliningrad Oblast of the Russian Federation. Aleksandra Jezierska-Thöle, Jörg Janzen and Roman Rudnicki compare the agrarian and economic structures of agricultural holdings in Poland and East Germany, while Agnieszka Kwiatek-Soltys and Helene Mainet focus on the quality of life in small French and Polish towns seen in terms of their attractiveness. The article by Marius Otto and Marta Chmielewska is also comparative in nature. It discusses the experiences of the Ruhr Basin and Upper Silesia in putting former industrial areas to a use intended to mitigate social polarisation. Like the two previous articles, this study is an example of animated scholarly cooperation developing between Polish geographers from various academic centres and their colleagues from abroad. It has intensified significantly after the 2004 enlargement of the European Union.

Also the next four articles are evidence of the developing scholarly contacts with Polish neigh-

\section{Andrzej Kostrzewski}

Editor-in-Chief

President of the Committee on Geographical Sciences

Polish Academy of Sciences bours. Two of them concern the Czech Republic. Jan Hercik, Petr Šimáček, Zdeněk Szczyrba and Irena Smolová discuss military brownfields in this country and their potential for revitalisation. This is a very important issue in both cognitive and practical terms, not only for the Czech Republic, but for all post-socialist states. In turn, Stanislav Kraft, Miroslav Marada and Dagmar Popjaková seek to delimit nodal regions in the Czech Republic on the basis of transport flows.

The object of research by Sławomir Dorocki is the spatial distribution of biotechnology centres in Germany, while Aleksander Kuczabski and Tomasz Michalski take the reader to Ukraine, a country of special interest today in the light of the recent political developments. The authors analyse the Ukrainian post-communist transformation, including its consequences and threats. This article is proof of how quickly contemporary geography responds to the pulse of life of the modern world, and how deeply embedded it is in an analysis of processes that determine the tendencies of its change.

We are proud that Quaestiones Geographicae has been a means of diffusion of the knowledge about those changes for the last 40 years. We hope that also this jubilee volume, prepared for the occasion of the 2014 IGU Regional Conference, will play this role and meet with a warm reception by the readers.

Tadeusz Stryjakiewicz Managing Editor

Human Geography and Spatial Management 